administration of betamethasone and triiodothyronine (T3) on development of functional pulmonary maturation in fetal rabbits. Biochem Biophys Res Commun 146:524-529

24. Hemberger JA, Schanker LS 1981 Effect of cortisone on permeability of the neonatal rat lung to drugs. Biol Neonate 40:99-104

25. Massaro D, Teich N, Maxwell S, Massaro GC, Whitney P 1985 Regulation and evidence for a critical period in rats. J Clin Invest 76:1297-1305

26. Ikegami M, Jobe A, Berry D 1986 A protein that inhibits surfactant in respiratory distress syndrome. Biol Neonate 50:121-129

27. Egan EA, Olver RE, Strang LB 1975 Changes in non-electrolyte permeability of alveoli and the absorption of lung liquid at the start of breathing in the lamb. J Physiol 244:161-179

28. Gonzales LW, Ballard PL, Ertsey R, Williams MC 1986 Glucocorticoids and thyroid hormones stimulate biochemical and morphological differentiation of human fetal lung in organ culture. J Clin Endocrinol Metab 62:678-691

29. Gross I, Wilson CM 1982 Fetal lung in organ culture IV: supraadditive hormone interactions. J Appl Physiol 52:1420-1425

30. Smith BT, Sabry K 1983 Glucocorticoid-thyroid synergism in lung maturation a mechanism involving epithelial-mesenchymal interaction. Proc Natl Acad Sci USA 80:1951-1954

31. Post M, Barsoumian A, Smith BT 1986 The cellular mechanism of glucocorticoid acceleration of fetal lung maturation. J Biol Chem 261:2179-2184

The Society for Behavioral Pediatrics will conduct its 7th Annual Meeting in Cambridge, MA on November 9-10, 1989. A special session honoring Dr. T. Berry Brazelton will be held on November 11, 1989. We invite you to submit abstracts of research papers for consideration for presentation at the scientific sessions. ABSTRACTS MUST BE RECEIVED BY APRIL 30, 1989. For further information and abstract forms, please contact: Ms. Noreen Spota, SBP Business Administrator, 241 East Gravers Lane, Philadelphia, PA 19118 (215) 248-9168.

\title{
Announcements
}

\section{Annual Meetings}

The American Pediatric Society, the Society for Pediatric Research, and the Ambulatory Pediatric Association will have meetings on May 1-5, 1989 at the Washington Sheraton Hotel, Washington, D.C.

Contact: SPR-Ms. Debbie Wogenrich, 2650 Yale Blvd., S.E., Suite 104, Albuquerque, NM 87106 (505) 7649099. APS-Dr. Audrey K. Brown, Secretary-Treasurer, Department of Pediatrics, SUNY, Health Science Center at Brooklyn, 450 Clarkson Avenue, Box 49, Brooklyn, NY 11203, (718) 270-1692. APA-Ambulatory Pediatric Association, 6728 Old McLean Village, McLean, VA 22101 (703) 556-9222.

\section{European Chief Editor}

Since the term of European Chief Editor Dr. Kari O. Raivio will expire at the end of 1989, the position of European Chief Editor of Pediatric Research will be open.

Duties include evaluation and editorial decisions regarding European manuscripts and collaboration with the Editor-in-Chief and the Board of Trustees of the International Pediatric Research Foundation toward developing the journal scientifically. Financial support for the office is provided.

Interested applicants should submit a curriculum vitae and the names of at least four local editors from different fields of pediatrics who would help evaluate manuscripts. Inquiries and applications should be sent by March 1, 1989 to: Dr. Kari O. Raivio, University of Helsinki, Children’s Hospital, 00290 Helsinki, Finland. 